\title{
Harnessing Untapped Biomass Potential Worldwide
}

\subsection{Introduction}

Biomass includes all kinds of non-fossil organic matter that is available on a renewable basis for conversion to energy and products. It is an abundant, geographically widespread, low sulfur, and carbon neutral fuel resource. It includes crops and agricultural residues, commercial wood and logging residues, animal wastes, and organic portion of municipal sold waste, and methane gas from landfills. According to the United Nations, biomass accounts for about $14 \%$ of world energy use and over one third of energy use in developing nations. It is estimated that the renewable, above ground biomass that could be harvested for power production is many times the world's total annual consumption.

Biomass-to-electricity power generation is a proven electricity generation option. Today in North America, biomass has $11 \mathrm{GW}$ of installed capacity and along with wind power is a significant source of non-hydro renewable electricity. More than 500 facilities around the U.S. are currently using wood or wood waste to produce combined heat and power. This installed capacity consists of about 7.0 GW from forest products and agricultural wastes, about 2.5 GW of municipal solid wastes (MSW) and 0.5 GW of landfill gas.

The majority of biomass used today is a residue produced either in the primary or secondary processing industries, or as post consumer residues. Many of the industries that process wood or sugar cane are themselves significant consumers of energy in the form of process heat and electricity so that this is a sector with a considerable amount of Rankine cycle combined heat and power (CHP) installations. However, many of them underutilize their residues. Post consumer residues, as urban wood and landfill gas, already make a significant power contribution in the United States, Europe and Japan. Large-scale expansion will require increased harvest residue collection and use in the form of forest thinnings, wood slash, straws and stalks from cereal crops, as well as the development of energy crops.

A U.S. supply curve for 2020 is discussed with its approximately 450 million tonne (Mt) potential, as well as a USA stretch potential for the middle of the century of a Gigatonne $(\mathrm{Gt})$.

Energy generation through the combustion of municipal waste is gaining in use. Recovering energy from garbage has evolved over the years from the simple incineration of waste in an uncontrolled, environmentally unfriendly way to the controlled combustion of waste with energy recovery, materials recovery and sophisticated air pollution control equipment insuring that emissions are within US and EU limits. The waste-to-energy industry has 
proven itself to be an environmentally friendly solution to the disposal of municipal solid waste and the production of energy. Recovering energy from the waste is an excellent idea and waste-to-energy is a clean, renewable, sustainable source of energy, and a common sense alternative to land filling.

Biomass is proven in many power-producing applications for base and intermediate load. Relative to conventional fossil fuels, however, biomass has relatively low energy density, requires significant processing, is an unfamiliar fuel among potential customers and is relatively expensive at the burner tip. In a world driven by calculations of rates of return to capital, biomass fuels are relegated to the position of an opportunity fuel with a large untapped potential in mainstream energy markets. Motivating the power industry to use more biomass fuels - to tap into the biomass energy potential - will require policy interventions from R\&D investments to tax and other policy incentives. Many policy interventions existing in the United States are compared to a few examples of the European approach.

Recent US experience on actual biomass demonstration projects illustrates the difference properly targeted policy incentive can have on biomass' ability to meet its untapped potential. As an example, the Antares Group Inc. is participating in several biomass power demonstration projects. These include switch grass co-firing in Iowa, willow and residue cofiring in New York State, and gasification for combined heat and power in Connecticut. It is policy incentives that make all these projects financially viable. An overview of these projects with and without the policy incentives makes that point clear.

The electricity production from biomass is and will continue to be used as base-load power in the existing electrical distribution system. A series of case studies are discussed for the three conversion routes for Combined Heat and Power applications of biomass-direct combustion, gasification, and co-firing. The cost of electricity and cost of steam as a function of variables such as plant size and feed cost are estimated using a discounted cash flow analysis described here.

Environmental considerations are also addressed. Two primary issues that could create a tremendous opportunity for biomass are global warming and the implementation of Phase II of Title IV of the Clean Air Act Amendment of 1990 (CAAA). The environmental benefits of biomass technologies are among its greatest assets. Global warming is gaining greater salience in the scientific community and among the general population. Co-firing biomass and fossil fuels and the use of integrated biomass gasification combined cycle systems can be an effective strategy for electric utilities to reduce their emissions of greenhouse gases.

As an example of a new bio-power option for distributed generation and CHP for rural enterprises, homes and small communities, the BioMax from Community Power Corporation (CPC) which uses a variety of biomass residues to provide power and heat is described, discussed, and evaluated. CPC's BioMax systems are skid-mounted, fully automated, environmentally friendly bio-power systems configured for combined heat and power applications that consist of an advanced and controllable downdraft gasifier integrated with an engine/generator that produces 5, 20 and $50 \mathrm{~kW}$ from producer gas. 
Included is an assessment of applicable technologies for rural development with Senegal Bio-Mass exploitation. This evaluates the latest technology options for utilizing feedstock from Senegal's groundnut industry in a mix with other government initiatives such as waste-to-energy programs. It assesses some of these technologies from the green power sector against local Senegal conditions. The implications for other Economic Community of West African States (ECOWAS) countries with similar rural supply challenges and other fuel source types are evaluated with recommendations.

\subsection{An Overview of Biomass Combined Heat and Power Technologies}

Bio-power is a commercially proven electricity generating option in the United States, and with about $11 \mathrm{GW}$ of installed capacity is a significant source of non-hydro renewable electricity. The capacity encompasses about 7.5 GW of capacity using forest product and agricultural industry residues, about 3.0 GW of MSW-based generating capacity and $0.5 \mathrm{GW}$ of other capacity such as landfill gas based production. Bio-power experienced a dramatic factor-of-three increase in grid-connected capacity after the Public Utilities Regulatory Policy Act (PURPA) of 1978 guaranteed small electricity producers (less than $80 \mathrm{MW}$ ) that utilities would purchase their surplus electricity at a price equal to the utilities' avoided cost of producing electricity. In the period 1980-1990, growth resulted in industry investment of $\$ 15$ billion dollars and the creation of 66,000 jobs

Today's capacity is based on mature, direct combustion boiler/steam turbine technology. The average size of bio-power plants is $20 \mathrm{MW}$ (the largest approaches $75 \mathrm{MW}$ ) and the average efficiency is $20 \%$. The small plant sizes (which leads to higher capital cost per kilowatt-hour of power produced) and low efficiencies (which increase sensitivity to fluctuation in feedstock price) has led to electricity costs in the 8-12 $\$ / \mathrm{kWh}$ range.

The next generation of stand-alone bio-power production will substantially mitigate the high costs and efficiency disadvantages of today's industry. The industry is expected to dramatically improve process efficiency through biomass co-firing in coal-fired power stations, through the introduction of high-efficiency gasification combined cycle systems, and through efficiency improvements in direct combustion systems made possible by the addition of dryers and more rigorous steam cycles at larger scale of operation. Technologies presently at the research and development stage, such integrated gasification fuel cell systems, and modular systems are expected to be competitive in the future.

A series of case studies [1] have been undertaken on the three conversion routes for CHP applications of biomass-direct combustion, gasification, and co-firing. The studies are based on technology characterizations developed by NREL and EPRI [2], and much of the technology descriptions given are excerpted from that report. Variables investigated include plant size and feed cost; and both cost of electricity and cost of steam are estimated using a discounted cash flow analysis.

The nearest term and lowest-cost option for the use of biomass is co-firing with coal in existing boilers. Co-firing refers to the practice of introducing biomass as a supplementary energy source in high efficiency boilers. Boiler technologies where co-firing has been practiced, tested, or evaluated, include wall- and tangentially-fired pulverized coal (PC) 
boilers, cyclone boilers, fluidized-bed boilers, and spreader stokers. Extensive demonstrations and trials have shown that effective substitutions of biomass energy can be made up to about $15 \%$ of the total energy input with little more than burner and feed intake system modifications to existing stations. After tuning the boiler's combustion output, there is little or no loss in total efficiency, implying that the biomass combustion efficiency to electricity would be about 33-37\%. Since biomass in general has significantly less sulfur than coal, there is a $\mathrm{SO}_{2}$ benefit; and early test results suggest that there is also a $\mathrm{NO}_{\mathrm{x}}$ reduction potential of up to $20 \%$ with woody biomass. Investment levels are very site specific and are affected by the available space for yarding and storing biomass, installation of size reduction and drying facilities, and the nature of the boiler burner modifications. Investments are expected to be in $\$ 100-700 / \mathrm{kW}$ of biomass capacity, with a median in the $\$ 180-200 / \mathrm{kW}$ range.

Another potentially attractive bio-power option is based on gasification. Gasification for power production involves the devolatilization and conversion of biomass in an atmosphere of steam or air to produce a medium- or low-calorific gas. This biogas is used as fuel in a combined cycle power generation cycle involving a gas turbine topping cycle and a steam turbine bottoming cycle. A large number of variables influence gasifier design, including gasification medium (oxygen or no oxygen), gasifier operating pressure, and gasifier type. The first generation of biomass GCC systems would realize efficiencies nearly double that of the existing industry. Costs of a first-of-a-kind biomass GCC plant are estimated to be in the $\$ 1800-2000 / \mathrm{kW}$ range with the cost dropping rapidly to the $\$ 1400 / \mathrm{kW}$ range for a mature plant in the 2010 time frame.

Direct-fired combustion technologies are another option, especially with retrofits of existing facilities to improve process efficiency. Direct combustion involves the oxidation of biomass with excess air, giving hot flue gases that produce steam in the heat exchange sections of boilers. The steam is used to produce electricity in a Rankine cycle. In an electricity-only process, all of the steam is condensed in the turbine cycle, while in CHP a portion of the steam is extracted to provide process heat. The two common boiler designs used for steam generation with biomass are stationary- and traveling-grate combustors (stokers) and atmospheric fluid-bed combustors. The addition of dryers and incorporation of morerigorous steam cycles is expected to raise the efficiency of direct combustion systems by about $10 \%$ over today's efficiency, and to lower the capital investment from the present $\$ 2,000 / \mathrm{kW}$ to about $\$ 1275 / \mathrm{kW}$.

Bio-power is unique among renewable energy sources because it involves combustion that releases air pollutants. Major emissions of concern from bio-power plants are particulate matter (PM), carbon monoxide (CO), volatile organic compounds (VOC), and nitrogen oxides $\left(\mathrm{NO}_{\mathrm{x}}\right)$. Biopower sulfur dioxide emissions are typically low because of the low amount of sulfur usually found in biomass. Actual amounts and the type of air emissions depend on several factors, including the type of biomass combusted, the furnace design, and operating conditions.

Life cycle assessment studies [3] have been conducted on various power generating options in order to better understand the environmental benefits and drawbacks of each technology. 
Material and energy balances were used to quantify the emissions, energy use, and resource consumption of each process required for the power plant to operate. These include feedstock procurement (mining coal, extracting natural gas, growing dedicated biomass, collecting residue biomass), transportation, manufacture of equipment and intermediate materials (e.g., fertilizers, limestone), construction of the power plant, decommissioning, and any necessary waste disposal.

The life cycle assessment studies have permitted the determination of where biomass power systems reduce the environmental burden associated with power generation. The key comparative results can be summarized as follows:

- The GWP of generating electricity using a dedicated energy crop in an IGCC system is $4.7 \%$ of that of an average U.S. coal system.

- Cofiring residue biomass at $15 \%$ by heat input reduces the greenhouse gas emissions and net energy consumption of the average coal system by $18 \%$ and $12 \%$, respectively.

- The life cycle energy balances of the coal and natural gas systems are significantly lower than those of the biomass systems because of the consumption of nonrenewable resources.

- $\quad$ Biomass systems produce very low levels of particulates, $\mathrm{NO}_{\mathrm{x}}$, and $\mathrm{SO}_{\mathrm{x}}$ compared to the fossil systems.

- System methane emissions are negative when residue biomass is used because of avoided decomposition emissions.

- Biomass systems consume very small quantities of natural resources compared to the fossil systems.

\subsection{Biomass Availability for BioPower Applications}

The estimation of biomass supplies is confounded by the many ways in which biomass is generated and used, especially as today the biomass for energy stream is composed of residues from primarily industrial and societal activities. Thus, the production of biomass feedstocks and bio-energy use is very dependent on the functioning of some other component of the economy, the three major areas being: forestry, agriculture, and the urban environment. While this includes a wide range of resources, ranging from primary residues through to post consumer residues, energy crops also have a significant potential.

To simplify the discussion of biomass it is necessary to provide some definitions and characterization of where in the economy biomass is generated or utilized as bio-energy. One methodology is to identify the stage of processing/utilization since the creation of the biomass by photosynthesis.

It is also necessary to note that there is no biomass currency such as the tonne of oil equivalent (toe). However, the majority of biomass is composed of lignin, cellulose, and hemicellulose polymers in proportions such that most lignocellulosics have a calorific value in the range of 17.5-18.6 GJ t-1 when measured on a totally dry basis. Each tonne of biomass has $5 \mathrm{MWh}_{\text {th }}$ energy content. A gigatonne has a $5 \mathrm{PWh}$ equivalent of primary energy. The 
world Total Primary Energy Supply (TPES) in 2001 was about 120 PWh. Current global estimates of future biomass potential are of the same order, though today the world biomass consumption is estimated at about $13 \mathrm{PWH}$ (TPES).

\subsubsection{Energy Crops}

Energy crops are a primary supply and involve the production and growth of biomass specifically for biomass to energy and fuels applications. This is widespread in developing countries for fuel wood, as well as examples of Eucalypt forestry for charcoal production in iron production in Brazil [4]. Also, in Brazil a significant fraction of the sugar cane crop is dedicated to ethanol production [5], while $9 \%$ of the U.S. corn harvest is used in the production of ethanol from starch [6]. Research and development in Europe and the United States is developing the use of woody or straw materials (lignocellulosics) as high yielding non-food energy crops. The impact of energy crops in moving the biomass supply away from what is available as a residue can be seen from the following example. Assuming a $38 \%$ efficiency, a $1 \mathrm{Mt}$ annual supply base can support a generating capacity of 225 - 240 MW operating at a $90 \%$ capacity. Using an energy crop yielding $15 \mathrm{tha}^{-1} \mathrm{y}^{-1}$ the area planted to the energy crop would need to be about $70 \mathrm{kha}$, representing less than $4 \%$ of the land area inside a circle of $80 \mathrm{~km}$ centered on the power plant. Typical ratios of energy out: fossil energy in, for such a plant, would be about 1:12 while the carbon dioxide emissions would be $<50 \mathrm{~g} \mathrm{kWh}^{-1}$, or even zero if the energy crop accumulates soil carbon at current anticipated rates.

\subsubsection{Primary Residues}

Primary residues are produced as a by-product of a primary harvest for another material or food use of grown biomass. A representative of this is the use of tops and limbs as well as salvage wood from forestry operations cutting saw-logs or pulpwood. This material along with forest thinning is a developing biomass supply system in Finland, for example [7]. Much of the research in the United States in recent years has focused on corn stover (Zea mays) as a large scale opportunity primary residue associated with the harvest of the principal grain crop [8].

\subsubsection{Secondary Residues}

The majority of biomass used today in the energy system is generated as secondary and tertiary residues. Secondary residues arise during the primary processing of biomass into other material and food products. Sugarcane bagasse is widely used to fuel CHP providing the heat and electricity needs of sugar processing as well as export of electricity to the grid. In the forest industries, black liquor from kraft pulping is a major fuel for $\mathrm{CHP}$ and the recovery of process chemicals. The meat, dairy, and egg production in concentrated animal feed operations (CAFO) is a rapidly growing area in which bio-energy production is part of the solution to environmental issues created by this landless food production system.

\subsubsection{Tertiary Residues}

Urban or post consumer residues are a major component of today's bio-energy system. In fact the official statistics of the IEA, for example, describe biomass as combustible 
renewables and waste, and in many countries the tertiary sector is captured under the title of municipal solid waste or MSW. The tertiary sector generates energy in combustion facilities as well as from the generation of methane as land fill gas (LFG) from properly managed burial of mixed wastes from cities. Methane is also produced in sewage treatment facilities. Individual rates of residue generation are currently about $22 \mathrm{MJ}$ person-1 $\mathrm{d}^{-1}$ in the United States; this combined with the high population densities of metropolitan areas, results in very high bio-energy potentials in this sector [9].

\subsubsection{Biomass Potential for 2020}

There is a consensus biomass resource potential estimate for 2020 in the United States, which captures most of the sources described above, other than the CAFO potential [10]. This is described in the form of a supply curve and indicates that there are about 7-8 EJ of primary energy at \# $4.0 \$ \mathrm{GJ}^{-1}$. This represents about $450 \mathrm{Mt}$ of dry lignocellulosic biomass potential, which can be compared with today's utilization of about 190 Mt. The ultimate technical potential for biomass in the United States is not yet established; however, work is underway on what is called the Gigatonne scenario, which would investigate the effect of seeking double the 2020 projection for say the 2040-2050 period.

\subsection{Thermo-chemical Technologies for Biomass Energy}

Biomass is a renewable resource that can be used for the production of a variety of products currently produced from fossil fuel resources [11]. Among these products are electric power, transportation fuels, and commodity chemicals. This diversity of products has encouraged development of "biorefineries" to replace traditional plants dedicated to the production of either electric power or manufactured products. Thermo-chemical technologies, including combustion, gasification, and pyrolysis, will play important roles in the development of biorefineries.

\subsubsection{Combustion}

Combustion for the generation of electric power is familiar to the utility industry, although fossil resources, especially coal, have been more commonly employed than biomass. As illustrated in Figure 3.1, solid-fuel combustion consists of four steps: heating and drying, pyrolysis, flaming combustion, and char combustion [12]. No chemical reaction occurs during heating and drying. Water is driven off the fuel particle as the thermal front advances into the particle. Once water is driven off, particle temperature increases enough to initiate pyrolysis, a complicated series of thermally driven reactions that decompose organic compounds in the fuel. Pyrolysis proceeds at relatively low temperatures in the range of $225^{\circ}-500^{\circ} \mathrm{C}$ to release volatile gases and form char. Oxidation of the volatile gases results in flaming combustion. The ultimate products of volatile combustion are carbon dioxide $\left(\mathrm{CO}_{2}\right)$ and water $\left(\mathrm{H}_{2} \mathrm{O}\right)$ although intermediate products can include carbon monoxide $(\mathrm{CO})$, condensable organic compounds, and soot.

Combustion of biomass in place of coal has several advantages including reduced emissions of sulfur and mercury [13]. Combustion of biomass has almost no net emission of greenhouse gases since the carbon dioxide emitted is recycled to growing biomass. Combustion of biomass, however, can still produce emissions of nitrogen oxides and 
particulate matter. Some biomass has high concentrations of chlorine, which is a precursor to dioxin emissions under poor combustion conditions. Although co-firing of biomass with coal offers some near-term opportunities for the utility industry, the need for higher efficiencies at smaller scales and the compelling opportunities for biorefineries suggest that gasification or pyrolysis will be better future options for using biomass.

Heating and Drying

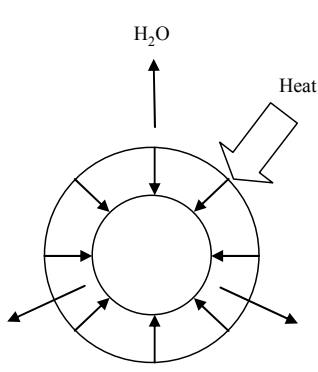

Thermal front

penetrates particle $\underline{\text { Pyrolysis }}$

Volatile gases:

$\mathrm{CO}, \mathrm{CO}_{2}, \mathrm{H}_{2}, \mathrm{H}_{2} \mathrm{O}$

light hydrocarbons, tar

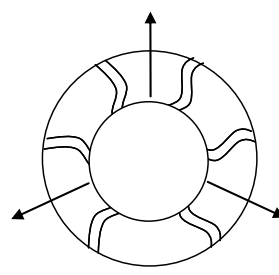

Porosity increases
Flaming Combustion

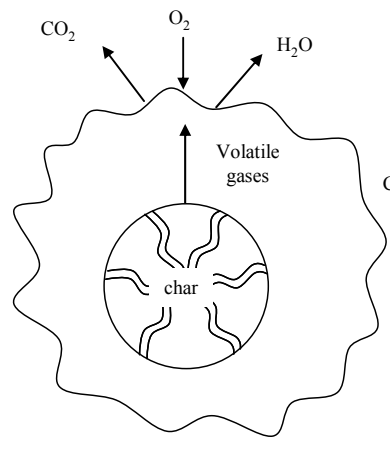

Flame front $\underline{\text { Char Combustion }}$

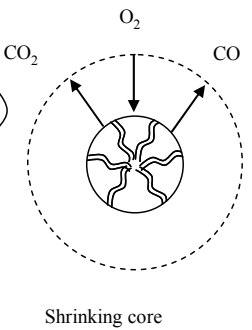

Fig. 3.1. Mechanism of Combustion

\subsubsection{Gasification}

Gasification is the partial oxidation of solid fuel at elevated temperatures to produce a flammable mixture of hydrogen $\left(\mathrm{H}_{2}\right), \mathrm{CO}$, methane $\left(\mathrm{CH}_{4}\right)$, and $\mathrm{CO}_{2}$ known as producer gas.

Figure 3.2 illustrates the four steps of gasification: heating and drying, pyrolysis, solid-gas reactions that consume char and gas-phase reactions that adjust the final chemical composition of the producer gas [14]. Drying and pyrolysis are similar to those processes during direct combustion. Pyrolysis produces char, gases (mainly $\mathrm{CO}, \mathrm{CO}_{2}, \mathrm{H}_{2}$, and light hydrocarbons) and condensable vapor. The amount of these products depends on the chemical composition of the fuel and the heating rate and temperature achieved in the reactor. Gas-solid reactions convert solid carbon into gaseous $\mathrm{CO}, \mathrm{H}_{2}$, and $\mathrm{CH}_{4}$. Gas phase reactions adjust the final composition of the product gas. Chemical equilibrium is attained for sufficiently high temperatures and long reaction times. Under these circumstances, products are mostly $\mathrm{CO}, \mathrm{CO}_{2}, \mathrm{H}_{2}$, and $\mathrm{CH}_{4}$. Analysis of the chemical thermodynamics of gasification reveals that low temperatures and high pressures favor the formation of $\mathrm{CH}_{4}$ whereas high temperatures and low pressures favor the formation of $\mathrm{H}_{2}$ and $\mathrm{CO}$.

Often gasifier temperatures and reaction times are not sufficient to attain chemical equilibrium and the producer gas contains various amounts of light hydrocarbons such as acetylene $\left(\mathrm{C}_{2} \mathrm{H}_{2}\right)$ and ethylene $\left(\mathrm{C}_{2} \mathrm{H}_{4}\right)$ as well as up to $10 \mathrm{wt}$ - $\%$ heavy hydrocarbons that condense to tar [15]. 
Heating and drying, pyrolysis, and some of the solid-gas and gas-phase reactions are endothermic processes, requiring a source of heat to drive them. This heat is usually supplied by admitting a small amount of air or oxygen into the reactor, which burns part of the fuel, releasing sufficient heat to support the endothermic reactions.

Producer gas can be used to fuel high efficiency power cycles like combustion turbines, fuel cells, and various kinds of combined cycles. Producer gas can also be used in chemical synthesis of transportation fuels, commodity chemicals, and even hydrogen fuel [11]. In spite of these advantages; gasification has technical hurdles to overcome before widespread commercialization. Challenges include increasing carbon conversion; eliminating particulate matter, tar, and trace contaminants in the producer gas; and increasing plant availability by developing more reliable fuel feed systems and refractory materials. If producer gas is to be used as fuel in high-pressure combustion turbines, efficient and economical methods for compressing the gas during or after gasification must be developed.

Heating and Drying

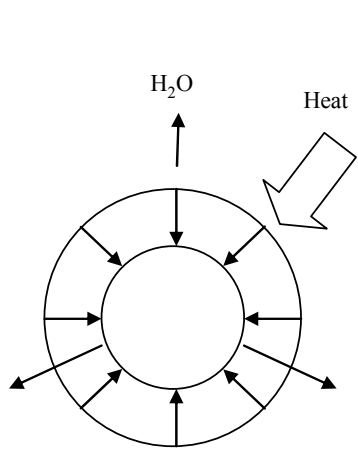

Thermal front penetrates particle $\underline{\text { Pyrolysis }}$

Volatile gases: $\mathrm{CO}, \mathrm{CO}_{2}, \mathrm{H}_{2}, \mathrm{H}_{2} \mathrm{O}$, Light hydrocarbons, tar

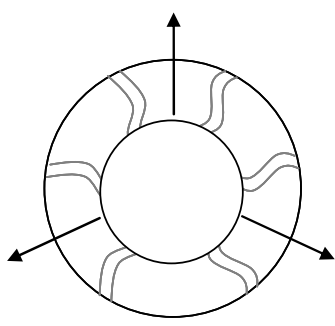

Porosity increases $\underline{\text { Gas-Solid Reactions }}$

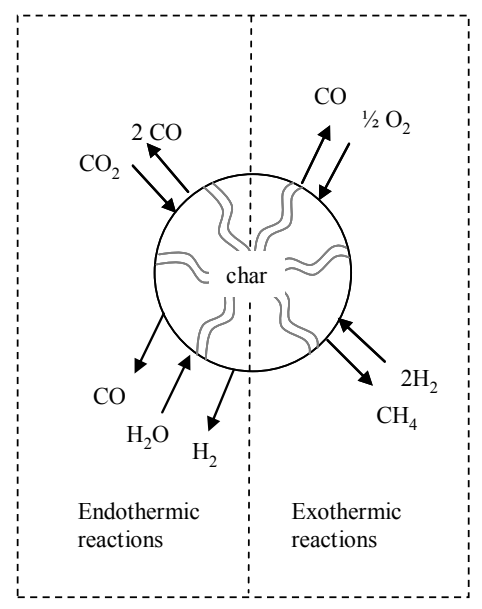

Fig. 3.2. Mechanism of Gasification

\subsubsection{Pyrolysis}

Pyrolysis is the heating of solid fuel in the complete absence of oxygen to produce a mixture of char, liquid, and gas. Although practiced for centuries in the production of charcoal, pyrolysis in recent years has been optimized for the production of liquids. In a process known as fast pyrolysis, chemical reaction and quenching proceed so rapidly that thermodynamic equilibrium is not attained, resulting in enhanced liquid yields on the order of $70 \mathrm{wt}$ \% of the original biomass [16]. This mixture of organic compounds and water is known as bio-oil. 
Bio-oil is a low viscosity, dark-brown fluid with up to 15 to $30 \%$ water, which contrasts with the black, tarry liquid resulting from slow pyrolysis or gasification. Fast pyrolysis liquid is a mixture of many compounds although most can be classified as acids, aldehydes, sugars, and furans, derived from the carbohydrate fraction, and phenolic compounds, aromatic acids, and aldehydes, derived from the lignin fraction. The liquid is highly oxygenated, approximating the elemental composition of the feedstock, which makes it highly unstable.

Figure. 3.3 illustrates the production of bio-oil, which begins with milling of biomass to fine particles of less than $1 \mathrm{~mm}$ diameter to promote rapid reaction. The particles are injected into a reactor, such as a fluidized bed, that has high heat transfer rates. The particles are rapidly heated and converted into condensable vapors, non-condensable gases, and solid char. These products are transported out of the reactor into a cyclone operating above the condensation point of pyrolysis vapors where the char is removed. Vapors and gases are transported to a quench vessel or condenser where vapors are cooled to liquid. The non-condensable gases are burned in air to provide heat for the pyrolysis reactor. A number of schemes have been developed for indirectly heating the reactor, including transport of solids into fluidized beds or cyclonic configurations to bring the particles into contact with hot surfaces.

Bio-oil can be used as a substitute for heating oil although its heating value is only about half that of its petroleum-based counterpart. Its handling and storage characteristics are inferior, as well. Nevertheless, the ability to produce liquid fuel from biomass offers opportunities for distributed production of a high-density fuel that can be easily pressurized for injection into combustion turbines. In addition, bio-oil contains a variety of organic compounds that, if they could be economically recovered, offer opportunities for pyrolysisbased bio-refineries.

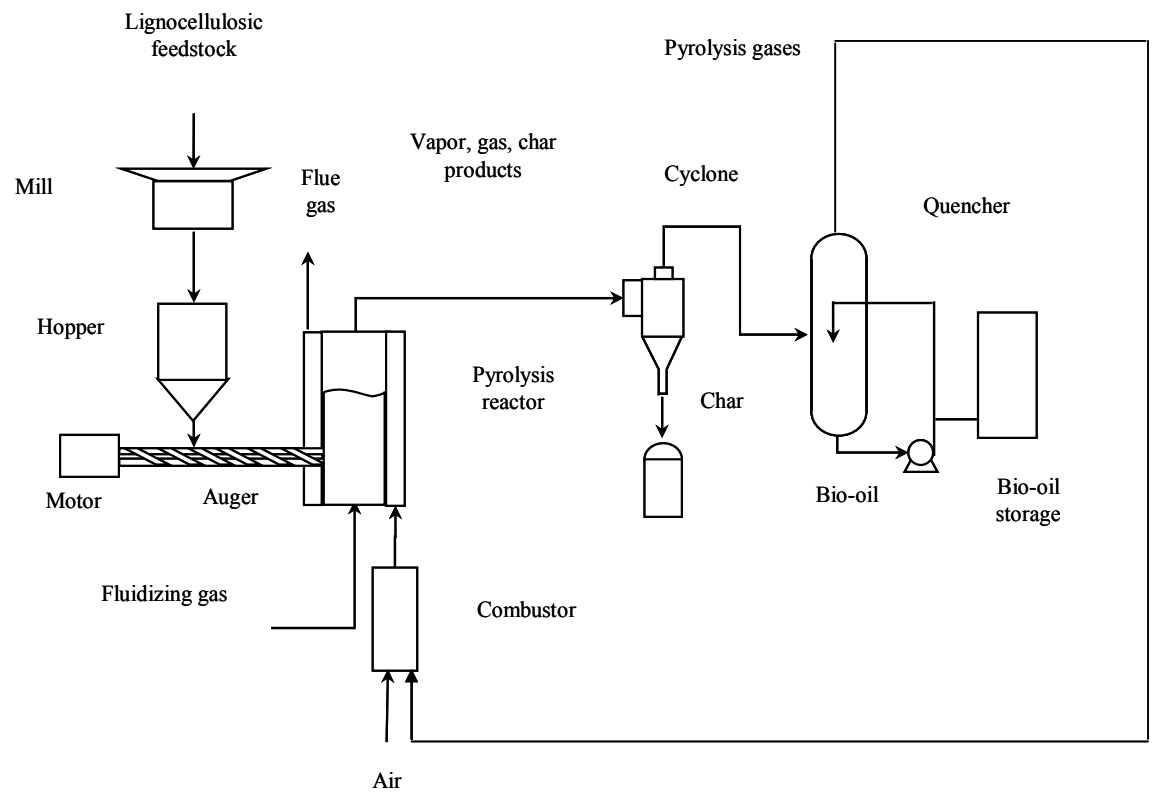

Fig 3.3 Schematic Illustration of Bio-Oil Production Facility 
In summary, a number of thermo chemical conversion processes are available to meet the growing demand for biomass energy. Biorefineries offer an intriguing future opportunity for the electric utility industry to meet this demand.

\subsection{The BioMaxTM---A New Biopower Option for Distributed Generation and CHP}

Access to reliable, utility-grade electricity is key to improving the quality and economy of life of many rural communities throughout the world. Conventional approaches to rural electrification such as grid extension or small diesel generators are increasingly prohibitive in cost and often environmentally harmful. The Community Power Corporation's (CPC) new BioMax small modular biopower systems offer an affordable and environmentally friendly means of using a variety of local forest and agricultural biomass residues to generate on-site the right amount of electricity and thermal energy needed by most rural enterprises, homes, hospitals, clinics, government offices, water pumps and community micro-grids.

\subsubsection{Technology}

Beginning in 1999, CPC joined with the US National Renewable Energy Laboratory (NREL) followed by Shell Renewables, the California Energy Commission and the US Forest Service to develop and bring to market a new generation of environmentally friendly small modular bio-power systems. The first BioMax prototypes ranging from $5 \mathrm{~kW}$ to $20 \mathrm{~kW}$ are now deployed in the Philippines and six locations in the USA. In January 2004, CPC signed follow-on contracts with the California Energy Commission and the US Forest Service to develop an advanced 50kW BioMax system for prime-power, distributed generation applications.

CPC's fully automated BioMax systems use a variety of biomass fuels to generate electricity and thermal energy. CPC's BioMax system (Figure 3.4) is designed as a "green" alternative to conventional fossil fuel generators and to free the community/user from dependence on the supply and high cost of imported fossil fuels such as gasoline or diesel fuel. By eliminating the need for importing diesel fuel, the community's financial resources are retained in the community and there is no environmental damage from spillage of diesel fuel or exhaust emissions. BioMax users with on-site woody residues avoid the high cost of waste disposal by generating power and heat from that waste. 


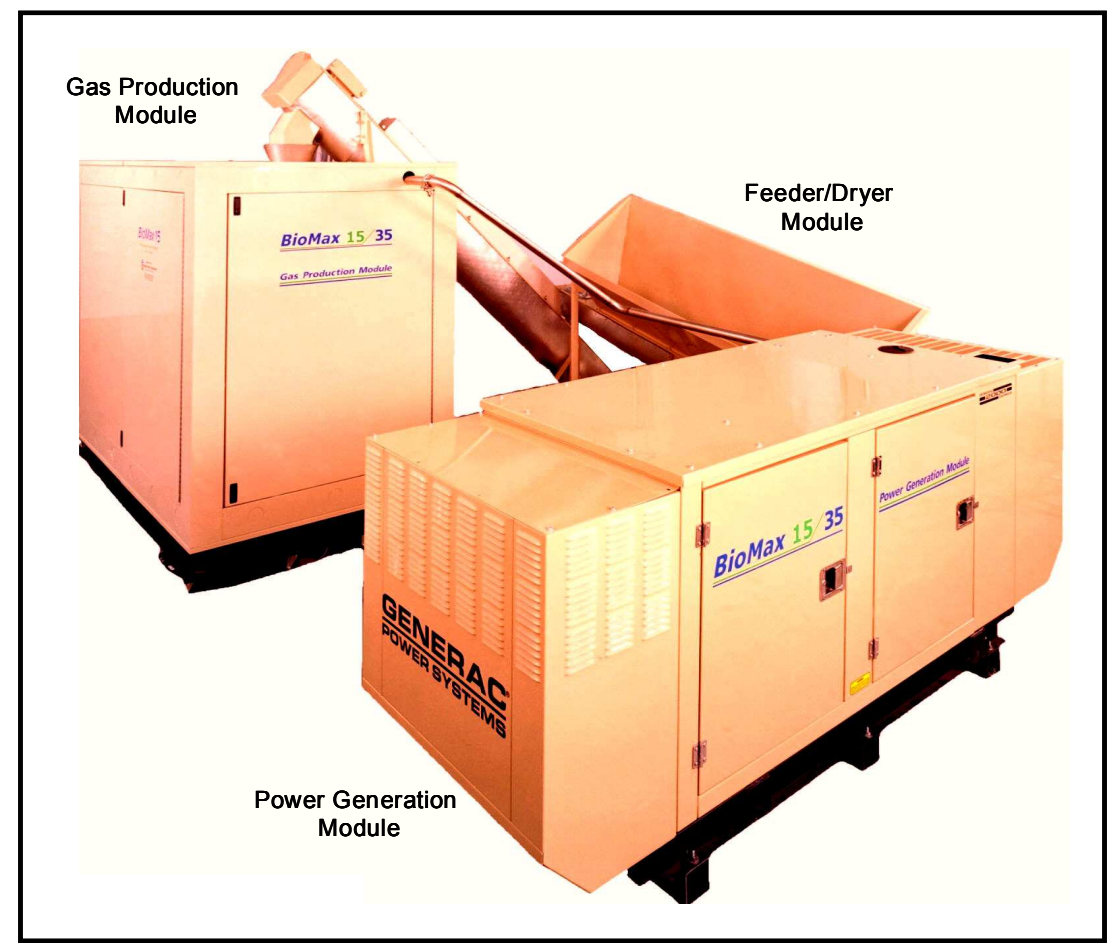

Fig. 3.4. BioMax 15/35

CPC's new bio-power technology incorporates the latest computer-based control technology and gasifier design to achieve unparalleled levels of clean-gas performance, turndown flexibility, and environ-mental friendliness. The "wood gas" is conditioned and fed into a standard internal combustion engine genset for conversion to mechanical, electrical, and thermal power. BioMax systems have also been used to operate a solid oxide fuel cell, a Stirling engine and a microturbine.

CPC's advanced design gasifier with fully integrated controls produces an extremely clean combustible gas from a variety of woody fuels including any kind of wood chips or densified biomass made from switch grass, sawdust, spent hops, grape skins, etc. Most nutshells including coconut, walnut, and pecan have proven to be an excellent fuel for the BioMax.

The small amount of byproduct char is entrained out of the gasifier and is removed from the producer gas stream by inertial separation and filtering. Very low tar levels in the producer gas are a result of automatic control of proper reactor temperatures over the full power range of the generator. The system does not produce condensed water nor does it use any form of liquid scrubbers. The only byproduct of the system is char and fine ash, the amount depending on the original ash content of the biomass feedstock. 
Waste heat from the hot producer gas is recovered and used for drying the wood-chip feedstock or for space heating. The moisture content of the feedstock is reduced about 15 percentage points during delivery from the feed hopper to the gasifier. The BioMax gasifiers have been successfully operated with woodchips having between about $5 \%$ and $25 \%$ moisture. Additional thermal energy is available from the engine coolant and exhaust.

The computer-based control system adjusts the fuel/air ratio in the engine and makes necessary adjustments to the process variables of the gasifier to maintain the desired temperature profile and gasifier bed porosity. The controller remotely alerts the operator if it cannot operate the system within specifications and gives the operator ample time to make corrections. If the operator is not available to refill the feed hopper or if the gasifier or engine/generator system continues to operate improperly, the "expert" controller will automatically (and independently) shut down the gasifier and engine system in a safe manner.

The BioMax line is undergoing a field-based beta testing program with a wide variety of users including a high school, furniture factory, wood shavings company, forest service facility, and a rural enterprise in the Philippines. There are also two BioMax systems at research institutions in the USA.

In summary, the BioMax line represents a new level of fully automated and environmental friendly bio-power systems designed for the $21^{\text {st }}$ century. On-going R\&D at Community Power Corporation's product development facility in Denver, Colorado will continue to achieve upgrades and performance enhancements in the areas of hot-gas filtration, feedstock variety, control systems, and cost reductions to increase the commercial viability of the systems.

\subsubsection{Summary of BioMax Features}

- Electrical output in blocks from 5kWe to 50kWe; 120 and 240 VAC; 50 and $60 \mathrm{~Hz}$

- Combined heat and power operation for rural electrification and distributed generation applications

- Environmentally friendly, non-condensing system without water scrubbers or liquid effluents

- Fully automatic, closed-loop control of all components including gasifier, gas conditioning and genset

- Dispatch able power within 30 seconds of auto-startup - uses no diesel fuel or gasoline

- Fuel flexible: wood chips, wood pellets, coconut shells, corn, corncobs, nutshells, etc.

- Optional automatic dryer/feeder for wood chips

- Modular, transportable, no need for on-site buildings or waste water disposal, 1 day installation. 


\subsubsection{Comparison of BioMax Bio-Power System} with other Power Generation Technologies

BioMax Bio-Power is compared with other Power Generation Technologies in Figure 3.5 and in Table 3.1.

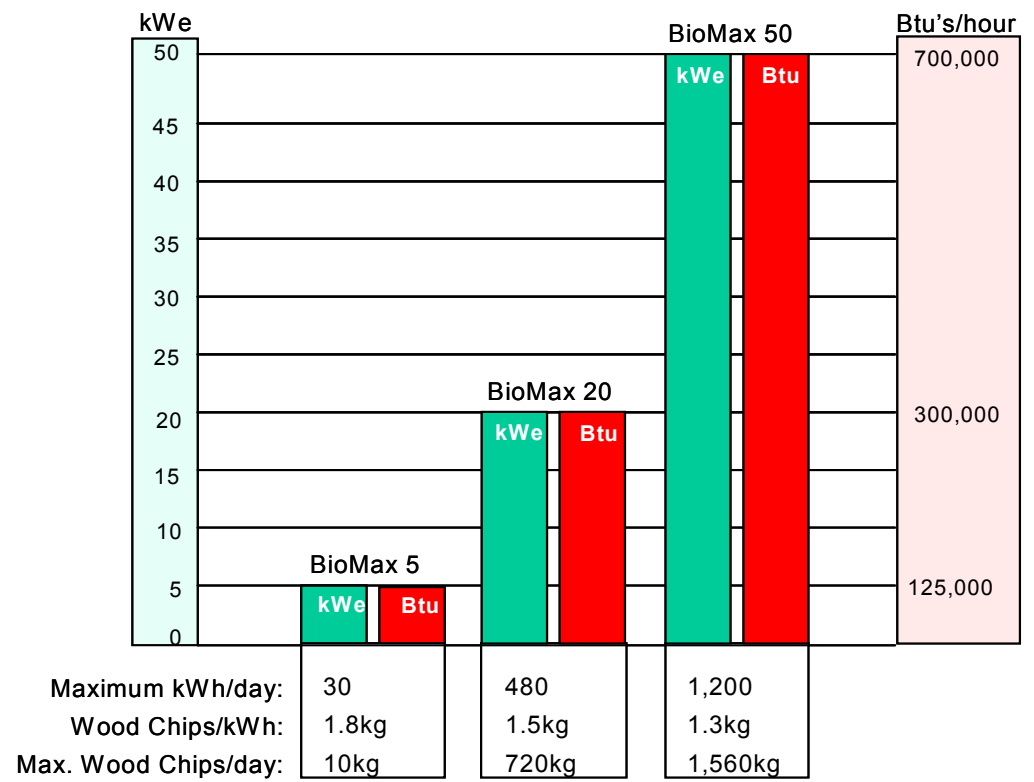

Source: Community Power Corporation

Fig. 3.5 BioMax Biopower CHP Systems 


\begin{tabular}{|c|c|c|c|c|c|c|}
\hline \begin{tabular}{|l|} 
COMPARISON \\
MATRIX
\end{tabular} & \begin{tabular}{|l|} 
BIOMAX \\
Community \\
Power Corp.
\end{tabular} & $\begin{array}{l}\text { PV } \\
\text { SYSTEM }\end{array}$ & \begin{tabular}{|l} 
DIESEL \\
GENERATOR
\end{tabular} & $\begin{array}{l}\text { FUEL } \\
\text { CELL }\end{array}$ & $\begin{array}{l}\text { MICRO- } \\
\text { TURBINE }\end{array}$ & $\begin{array}{l}\text { SMALLWIND } \\
\text { TURBINE }\end{array}$ \\
\hline kW Range & $5-100$ & $2.5-15$ & $5-6,000$ & $5-3,000$ & $30-400$ & $3-200$ \\
\hline $\begin{array}{l}\text { Capacity } \\
\text { compared }\end{array}$ & $20 \mathrm{~kW}$ & $15 \mathrm{~kW}$ & $15 \mathrm{~kW}$ & $15 \mathrm{~kW}$ & $30 \mathrm{~kW}$ & $10 \mathrm{~kW}$ \\
\hline $\begin{array}{l}\text { Stand-alone } \\
\text { svstem }\end{array}$ & yes & yes & yes & yes & yes & yes \\
\hline $\begin{array}{l}\text { Dispatchable } \\
\text { Power }\end{array}$ & yes & no & yes & yes & yes & no \\
\hline $\begin{array}{l}\text { Installed } \\
\text { Capital } \\
\text { Cost, } \$ / \mathrm{kW}\end{array}$ & $\$ 1,200-\$ 4,000$ & $\$$ & $\$ 200-$ & $\begin{array}{l}\$ 3,000- \\
\$ 4,000\end{array}$ & $\begin{array}{l}\$ 1,200 \\
\$ 1,700\end{array}$ & $\$ 2,000-\$ 3,000$ \\
\hline $\begin{array}{l}\text { Combined Heat } \\
\text { and Power? }\end{array}$ & Yes & No & Yes & Yes & Yes & No \\
\hline \begin{tabular}{|l} 
Electrical \\
system \\
efficiency
\end{tabular} & $20-22 \%$ & $\begin{array}{r}6 \\
12 \%\end{array}$ & $35 \%$ & $36-50 \%$ & $14-30 \%$ & $25 \%$ \\
\hline $\begin{array}{l}\text { Overall } \\
\text { Efficiency }\end{array}$ & $80-85 \%$ & $\begin{array}{r}6 \\
12 \% \\
\end{array}$ & $80-85 \%$ & $80-85 \%$ & $80-85 \%$ & $25 \%$ \\
\hline Fuels & \begin{tabular}{|l|} 
Fuel flexible: \\
straight biomass \\
or dual fuel with a \\
fossil \\
generator: diesel or \\
LPG
\end{tabular} & None & Diesel fuel & $\begin{array}{l}\text { Hydrogen, } \\
\text { natural } \\
\text { gas or } \\
\text { propane }\end{array}$ & $\begin{array}{l}\text { Natural } \\
\text { gas or } \\
\text { propane }\end{array}$ & None \\
\hline Fuel cost & \begin{tabular}{|l} 
Biomass: \\
$\$ 0 \quad-0.04 / \mathrm{kWh}$ at \\
$\$ 0.02 / \mathrm{kg}$ \\
Diesel: \\
$\$ \quad 0.10 / \mathrm{kWh}$ at $\$$ \\
$1.35 / \mathrm{gal}$
\end{tabular} & $\$ 0$ & $\begin{array}{l}\$ 0.10 / \mathrm{kWh} \\
@ \$ 1.35 / \mathrm{gal}\end{array}$ & $\begin{array}{l}\$ 0.08 / \mathrm{kW} \\
\mathrm{h} \\
@ \\
\$ 1.35 / \mathrm{gal} \\
\text { equivalent }\end{array}$ & $\begin{array}{l}\$ \\
0.15 / \mathrm{kWh} \\
\text { at } \\
\$ 1.35 / \mathrm{gal} \\
\text { equivalent }\end{array}$ & $\$ 0$ \\
\hline $\begin{array}{l}\text { Variable } \\
\text { O\&M }(\$ / k W h)\end{array}$ & $0.005-0.015$ & $\begin{array}{l}\$ 0.001- \\
0.004\end{array}$ & $\$ 0.005-0.015$ & $\begin{array}{l}\$ 0.0019- \\
0.0153\end{array}$ & $\begin{array}{l}\$ 0.003- \\
0.008\end{array}$ & $\$ 0.01$ \\
\hline $\begin{array}{l}\text { Energy density } \\
(\mathrm{kW} / \mathrm{M} 2)\end{array}$ & 30 & 0.02 & 50 & $1-3$ & 59 & .01 \\
\hline $\begin{array}{l}\text { Needs battery } \\
\text { storage }\end{array}$ & No & Yes & No & No & No & Yes \\
\hline \begin{tabular}{|l|} 
Needs power \\
conditioning
\end{tabular} & No & Yes & No & Yes & Yes & Yes \\
\hline
\end{tabular}

Table 3.1Equipment by Comparison

\subsection{Motivating the Power Industry with Biomass Policy and Tax Incentives}

Biomass is an abundant, geographically widespread, low sulfur, carbon neutral fuel resource. It is proven in many power-producing applications for base load and intermediate load. However, relative to conventional fossil fuels, biomass has relatively low energy density, requires significant processing, is an unfamiliar fuel among potential customers and 
is relatively expensive at the burner tip. In a world driven by calculations of rates of return to capital, biomass fuels are relegated to the position as an opportunity fuel with a large untapped potential in mainstream energy markets. Motivating the power industry to use more biomass fuels - to tap into the biomass energy potential - will require policy interventions from $R \& D$ investments to tax and other policy incentives. This discussion will focus on many of the policy interventions existing in the United States and those proposed in the Energy Bill before the U.S. Congress. By way of comparison, a few examples of the European approach will be discussed. Recent U.S experience on actual biomass demonstration projects will illustrate the difference properly targeted policy incentive can have on biomass' ability to meet its untapped potential.

The Antares Group Inc. is participating in several biomass power demonstration projects. Among them are switchgrass co-firing in Iowa, willow and residue co-firing in New York State, and gasification for combined heat and power in Connecticut. A recent "Healthy Forests" initiative proposed by the Bush Administration, led to a comprehensive review of commercially viable biomass systems for use with forest thinning in rural areas. It is policy incentives that make all these projects financially viable. An overview of these projects with and without the policy incentives will make that point clear.

\subsection{Energy Generation through the Combustion of Municipal Solid Waste}

\subsubsection{The Concept}

Recovering energy from waste, or waste-to-energy (WTE) as it's called in the U.S., isn't a new idea but it has evolved over the years from the simple incineration of waste in an uncontrolled, environmentally unfriendly way to the controlled combustion of waste with energy recovery, materials recovery and sophisticated air pollution control equipment insuring that emissions are within U.S. and EU limits [17]. This process took over 50 years of development and many improvements in design and technology, but the waste-to-energy industry has proven itself to be an environmentally friendly solution to the disposal of municipal solid waste and the production of energy. Modern WTE facilities reduce the volume of incoming municipal solid waste (MSW) by $90 \%-95 \%$ creating energy and jobs in the process and extending the life of landfills by generations. Many major metropolitan areas worldwide have facilities capable of processing 1,000, 2,000 and 3,000 tons of MSW a day with energy production in the form of steam and/or electricity.

Barlow Projects has come up with an innovative combustion system and facility design tailor made for those smaller communities with only 100 to 500 tons a day of waste. In some cases this means a collection of communities or districts pooling their waste and bringing it to a central location for processing. This may solve the landfill capacity problem for an entire region while simultaneously providing a predictable waste disposal fee, energy and the creation of new jobs.

\subsubsection{Technical Challenges}

Municipal solid waste is a difficult fuel to burn. Its non-homogenous nature complicates fuel handling and fuel feeding as well as ash handling. Controlling furnace temperature is critical to managing this process. Additionally, the fuel stream requires sophisticated air 
pollution control and emissions monitoring equipment to deal with acid gases and metals emissions that result from MSW combustion. Steam generation is accomplished with water wall or waste heat boilers. In both cases, tube corrosion is an issue due to high combustion temperatures and elevated levels of sulfur oxides and hydrogen chloride. Limiting tube metal temperatures is key to avoiding high temperature corrosion, particularly in super heater tubes. Air pollution control technologies for MSW combustion have advanced significantly in the last two decades. Stringent emissions standards for a variety of constituents mandate effective control and the industry has risen to these challenges. Most facilities are now equipped with scrubbers, activated carbon injection systems, bag houses and in some cases SNCR systems, but CO must be controlled at the front end by carefully monitoring and controlling the combustion process. Additionally, capital and operating costs must be minimized especially for smaller scale projects. Employing an "all-dry" reagent system provides excellent removal efficiencies without a sizeable increase in costs.

\subsubsection{Biomass and Renewable Status}

As far as the technology has come, one of the great challenges to WTE today is its status as a renewable fuel. Like any power plant, WTE facilities don't get built unless the economics work. WTE facilities must balance the revenue from accepting the waste, (referred to as the tipping fee) and the price of the energy it is able to sell in the form of steam or electricity, with the debt service and operational expenses of the facility. Because electricity rates are so low in many parts of the country, getting a 1.5 cent per KWh credit for electricity sold can make the difference between the project getting built or not. The DOE has classified MSW as Biomass for years [18] but, although qualifying as Biomass is generally the standard for gaining acceptance as Renewable, many environmental activists object to this notion and are having some success preventing these projects from benefiting from state or federal tax credits. The Energy Bill in Conference Committee as of the writing of this paper currently has sections specifically dealing with energy generated from Biomass, Municipal Solid Waste and a national Renewable Portfolio Standard (RPS) [19]. An RPS would require federal agencies to buy a certain percentage of their power from renewable technologies. A tax credit for power generated from new WTE facilities would, perhaps, provide the incentive needed to re-ignite the WTE industry and get more of these facilities built. An RPS would insure there was a client to purchase the power generated by these facilities. Additionally, non-governmental organizations like "Green-E" have set up programs to certify that certain types of energy are "green". Some utilities use this unofficial certification as their standard for marketing that energy as part of their green portfolio. Unfortunately, "Green-E" does not use the same guidelines as the US DOE for deciding what is renewable or "green" and what isn't and WTE is not currently eligible for their certification.

\subsubsection{Public Acceptance}

Despite the fact that the EPA recently released a report praising the WTE industry as being a "clean, reliable, renewable source of energy" [20], many still have a negative perception of waste-to-energy. This may be due, in part, to the fact that at one time there were over 700 incinerators operating in the United States burning trash without energy recovery or air pollution control equipment [21]. The majority of those chose to shut down when faced with installing the expensive air pollution control equipment mandated by the Clean Air Act, but 
not enough time has passed to erase these perceptions. Fortunately, the new air pollution control equipment being used is up to the task and modern facilities are meeting new stringent EPA emissions requirements. Additionally, EPA has done exhaustive studies to determine the safe exposure levels of the constituents that could potentially be emitted from a WTE facility and independent studies have determined that the actual amounts emitted do not present a significant threat to human health [22]. There are WTE facilities located in the middle of small communities, in large cities, on college campuses and near hospitals. Those who tour WTE facilities are often amazed that odors are minimal outside the facility and that there is no smoke coming out of the stack. It is those environmentalists that cling to old data and unsound concepts about what could be done with the waste rather tan presenting the challenge to public acceptance. Concepts like "zero waste" which advocate unrealistic recycling levels.

And what about recycling? Can't one just recycle everything so that there isn't anything left for landfilling or incineration? Don't WTE facilities compete with recycling and burn up valuable resources? With all the talk about recycling and the progress that's been made toward source reduction, composting and other forms of diversion, American's still send about 130 million tons of garbage to landfills every year [23]. Even the most efficient recycling programs are only diverting $50 \%$ of the waste stream leaving the other $50 \%$ to be managed in some other way. The bottom line is that some forms of waste are just not suitable for recycling because it isn't economical to do so. By removing those items from the waste stream that can and should be recycled one can improve the quality of the fuel and improve the efficiency of the combustion system. This does not mean that one shouldn't keep trying to manufacture goods in such a way that makes them more amenable to recycling and that one shouldn't continue to work towards higher diversion rates, but at best, only a portion of the problem is addressed. As a species, we are currently entombing millions of tons of fuel in the earth in the form of refuse that could be used to generate heat or electricity through the WTE process. This fuel has a heating value approaching $1 / 2$ that of coal [24]. Why wouldn't we take advantage of that?

\subsubsection{Potential}

A Modern 500 ton/day Resource Recovery facility will generate approximately $10 \mathrm{MWs}$ of energy. Currently only about $15 \%$ of America's municipal solid waste is combusted in 98 WTE facilities [25]. If additional WTE facilities were built to combust the waste we are currently landfilling, the potential for energy generation in America alone is approximately $8700 \mathrm{MW}$ of what can legitimately be called renewable, sustainable energy. The demand overseas is even greater as many European countries are running out of landfill space and outlawing landfilling altogether. Outside the U.S. there have been over 60 new WTE plants built since 1996 [26]. Small island nations are also ripe for WTE projects because once their landfill is full, they have no other option than to ship it off island at great cost. Even in the United States, the landfills in rural areas are filling up, leaving many communities with no other option than to long-haul their waste to one of the many mega-landfills built to serve the big cities. This is not only expensive but contributes to the ever-growing number of semi-trailers on our roadways. Semi-trailers that are usually traveling empty one way. 
The bottom line is that recovering energy from waste that we throw away is still a good idea and, despite some misconceptions, Waste-to-Energy is now a clean, renewable, sustainable source of energy, and a common sense alternative to landfilling. U.S. counties, municipalities, solid waste authorities and energy companies should re-consider this alternative to burying this fuel in a hole.

\subsection{Senegal Bio Mass Exploitation: An assessment of applicable technologies for rural development}

The UNDP World energy assessment report [27] is comprehensive in addressing the scope of energy options and their implications worldwide but its importance is the focus it places on the 2 billion people on the planet with no access to electricity.

In fact, 2 billion people-one third of the world's population-rely almost completely on traditional energy sources and so are not able to take advantage of the opportunities made possible by modern forms of energy [27-29]. Moreover, most current energy generation and use are accompanied by environmental impacts at local, regional, and global levels that threaten human well-being now and well into the future. In Agenda 21 the United Nations and its member states have strongly endorsed the goal of sustainable development, which implies meeting the needs of the present without compromising the ability of future generations to meet their needs. The importance of energy as a tool for meeting this goal was acknowledged at every major United Nations conference in the 1990s, starting with the Rio Earth Summit (UN Conference on Environment and Development) in 1992 [30].

Section 3.8 therefore attempts to illustrate partial solutions to produce sustainable electricity from Senegal's groundnut industry and the benefits to rural communities in the immediate vicinity of processing facilities.

\subsubsection{Innovative Renewable Energy Technology for Rural Enterprise}

The following excerpt from a recent study illustrates the reality of energy deficiencies and available opportunities:

With a groundnut production of about 1 million t per year, Senegal (Figure 3.6) is one of the most important countries of the world. With $80 \%$ of this production for export, Senegal is the world's largest groundnut exporting country. Its major export products are groundnuts for eating, groundnut oil and groundnut pellets as a fodder, made from groundnut cake. The town of Kaolack being the provincial capital of the Kaolack province lies in the centre of the groundnut-growing region and has two groundnut processing plants with a combined capacity of 250,000 $\mathrm{t}$ per year. One of these plants is NOVASEN. In 1999, it started production in newly installed plant in the industrial zone at Kaolack harbour. NOVASEN uses a modern press process, which yields $92 \%$ of oil in one go from the groundnut kernel (conventional procedures have a maximum yield of $80 \%$; therefore, in a second stage another 10 to $15 \%$ has to extracted from the groundnut cake, by chemical means). The new process has increased energy efficiency, thus NOVASEN does not need to burn the groundnut shells to generate the energy needed for the plant, as in conventional groundnut processing. On account of this, the NOVASEN plant in Kaolack produces about 10,000t to 
$15,000 \mathrm{t}$ of groundnut shells per year, which are, at present, is not used in other ways. NOVASEN intends to carbonize these groundnut shells in a modern retort and to use all of its by-products (flue gases, pyrolysis oil) as a source of energy in its groundnut processing plant. An industrial briquetting plant is expected to produce about 3,000 to 4,000 t high-quality biocoal per year for the local charcoal market at Kaolack or other urban centres in Senegal. At present, about 360,000t charcoal are consumed each year in Senegal, which are produced locally in traditional earth kilns from Senegal's forest resource. According to official estimates, between 50,000 and 80,000 ha of forest cover are lost annually on account of charcoal production with goes in line with claiming agricultural land. Under this situation, the planned NOVASEN project does not only constitute a very effective rational use of energy measure in industry, but also an important contribution to the protection of natural resources in Senegal. In traditional charcoal kilns with only $17 \%$ efficiency, some 18,000 t of wood would be needed to make 3,000 $\mathrm{t}$ of charcoal - this amount of wood could be saved every year through the planned NOVASEN carbonisation and briquetting plant [31, 32].

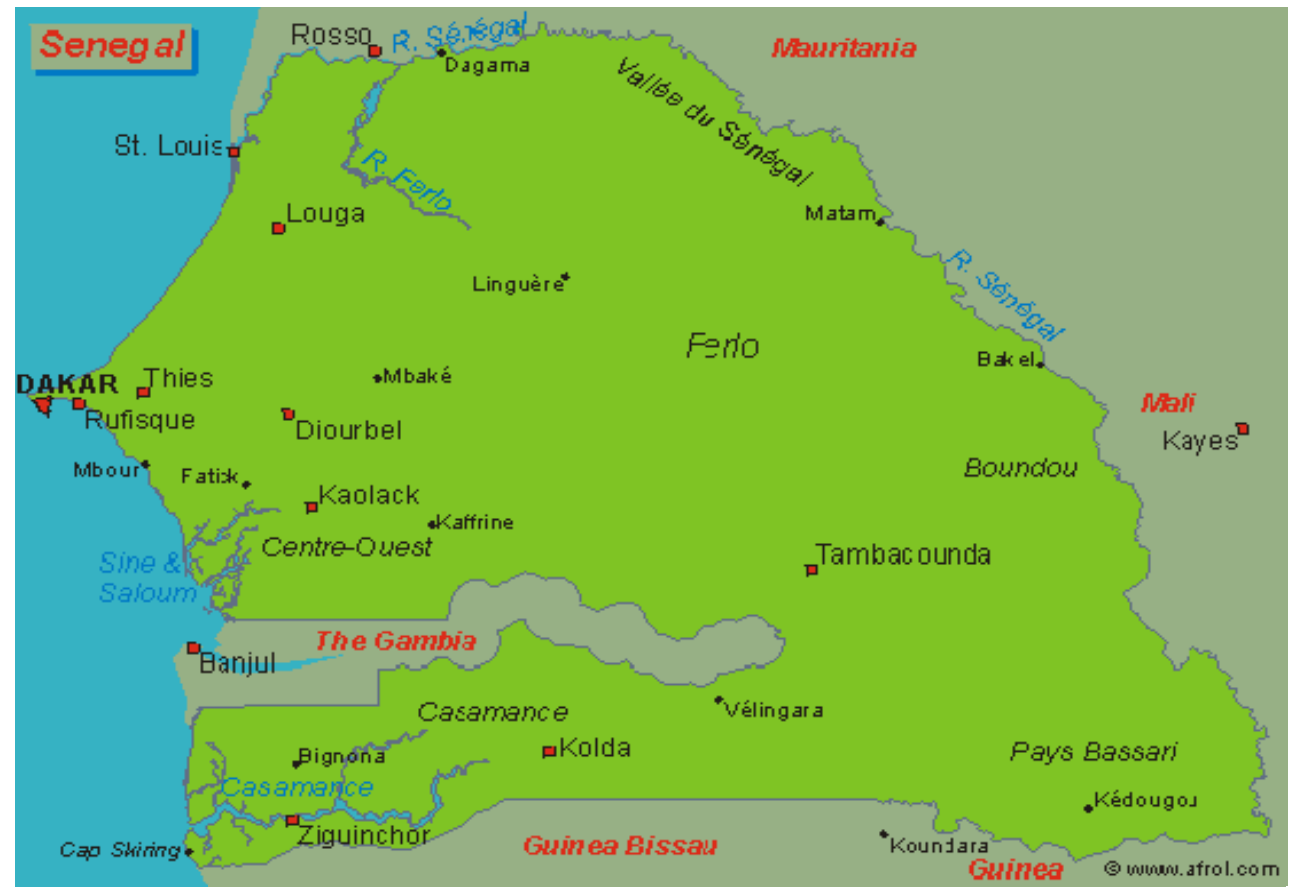

Fig. 3.6. Senegal

\subsubsection{The BioMax System}

An advanced small modular bio-power (SMB) system that may be very appropriate for Senegal and other ECOWAS countries has been developed by US-based Community Power corporation (CPC) 1 for markets worldwide. The system is known as the Community Productive Use Platform (C-PUP), and produces thermal energy, shaft power, and electricity. The C-PUP incorporates a CPC BioMax bio-energy system. BioMax is the trade name used 
by Community Power Corp. for its small modular bio-power (SMB) systems that convert woody biomass residues to electricity, shaft power, and thermal energy. The C-PUP converts locally available biomass into useful mechanical, electrical, and thermal power that can be applied to a myriad of productive use applications. The heart of the CPUP is CPC's Gas Production Module (GPM) that converts coconut shells (and other dry woody biomass) to a product gas for delivery to a spark-ignited engine mounted on a power distribution platform. The gasifier converts biomass by low-oxygen thermal decomposition into a gas mixture that is primarily composed of hydrogen, carbon monoxide, methane, carbon dioxide, and water vapor. The platform can allocate shaft power as needed to various mechanical and electrical loads including motors and compressors.

The peak electrical output of the BioMax 15 unit in the CPUP is $15 \mathrm{kWe}$ from the conversion of about $23 \mathrm{~kg}$ of coconut shells per hour. In addition, about $20 \mathrm{~kW}$ of thermal energy is available in the form of clean, hot air for drying crops and fish [33].

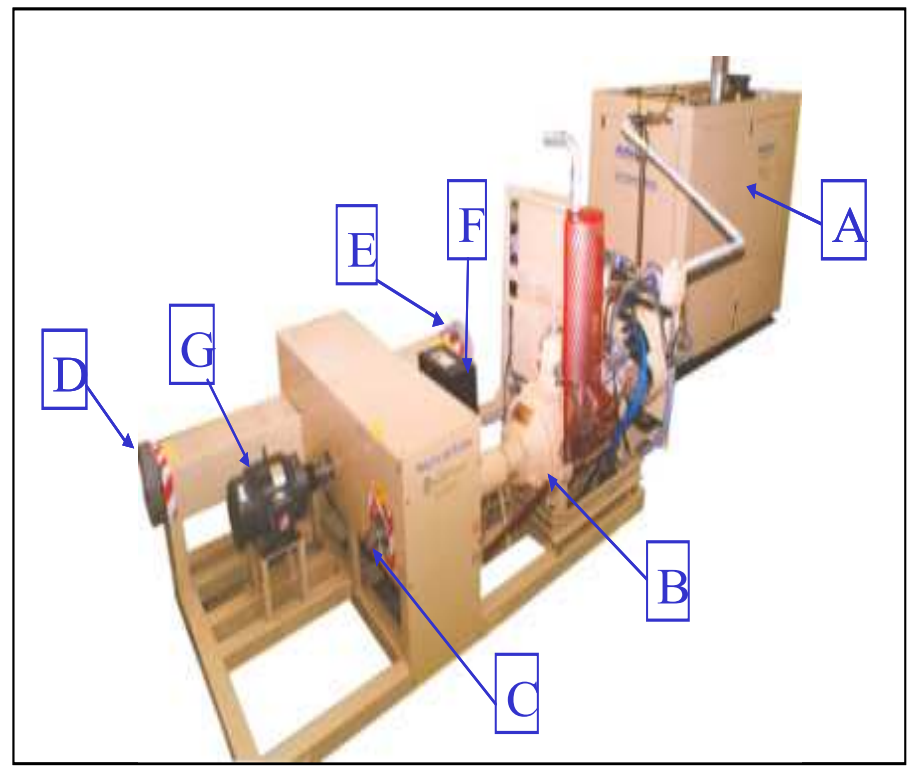

Fig. 3.7. The SMB Community Productive Use Platform

The Gas Production Module (A) (Figure 3.7) converts woody biomass to a fuel gas that is ignited in an engine (B) to turn a shaft. The shaft power is distributed to output (C) to run a small biomass fuel grinder (not shown); to outputs (D) and (E) for powering a variety of larger implements such as flour mills, rice mills, decorticators, composters, water pumps, etc. (not shown). Any combination of these mechanical outputs can be engaged, or disengaged simultaneously. If electrical power is needed, a $15 \mathrm{~kW}$ generator $(\mathrm{F})$ can be engaged. If the Gas Production Module or engine are not available, motor (G) can be connected to a backup electrical power source to drive any combination of mechanical 
outputs (C, D and E). All rotating shafts, belts, pulleys, and heated surfaces are covered for worker safety.

\begin{tabular}{|l|l|l|l|}
\hline & BioMax 5 & BioMax 20 & BioMax 50 \\
\hline Max. kWh/day: & $30-50$ & 480 & 1,200 \\
\hline Shells/kWh (est.): & $3.5 \mathrm{~kg}$ & $3 \mathrm{~kg}$ & $2.5 \mathrm{~kg}$ \\
\hline Max.Shells/day: & $120-175 \mathrm{~kg}$ & $1,440 \mathrm{~kg}$ & $3,000 \mathrm{~kg}$ \\
\hline
\end{tabular}

Table 3.2 Groundnut Shell Feedstock

Senegal's yield in excess of $10,000 \mathrm{~T}(9,071,847 \mathrm{~kg})$ groundnut shell feedstock can produce very significant amount of on and off grid electricity per the kWh production yields shown in Table 3.2.

The secondary use of waste being looked at needs to be evaluated not just as a source of available electricity supply but also as prime movers that can drive 'strategic loads'. Strategic loads in this context imply clusters of strategic entities. In turn those strategic entities as collective units themselves become 'Prime Movers' in that they have direct evolutionary impacts on society.

\subsection{Acknowledgement}

This Chapter has been prepared by Peter Meisen, President, Global Energy Network Institute (GENI), San Diego, CA, USA. Contributors include Richard L. Bain (Group Manager and Principal Researcher, Thermo Chemical Conversion Group, National Renewable Energy Laboratory (NREL), Golden, CO, USA). Ralph P. Overend (NREL, Golden, CO, USA), Robert C. Brown (Bergles Professor of Thermal Science, Department of Mechanical Engineering, Iowa State University (ISU), USA), Robb R. Walt (President and CEO, Community Power Corporation, Littleton, CO, USA), Christian Demeter (Vice President American Bio-energy Association, USA), Gregg Tomberlin (Barlow Projects, Inc., Fort Collins, CO, USA)., and Soungalo Sanoko (Technical Director, SONACOS, Dakar, Senegal). The Chapter is primarily based on an up-date of the invited panel session summary papers presented at the Panel Session on Harnessing Untapped Biomass Potential Worldwide at the IEEE-PES 2004 General Meeting (GM2004)

\subsection{References}

[1] Bain, R. L.; Amos, W. P.; Downing, M.; Perlack, R. L. (2003). Biopower Technical Assessment: State of the Industry and the Technology. 277 pp; NREL Report No. TP-510-33123.

[2] "Renewable Energy Technology Characterizations," (1997). EPRI-TR-109469, Electric Power Research Institute, Palo Alto, California, December.

[3] Mann, M.K.; Spath, P.L. (2000). A Comparison of the Environmental Consequences of Power from Biomass, Coal, and Natural Gas. First World Conference and Exhibition on Biomass for Energy and Industry. June 5-9, Seville, Spain.

[4] Rossillo-Calle, F. and G. Bezzon, Production and use of industrial charcoal, in Industrial Uses of Biomass Energy: The example of Brazil, F. Rossillo-Calle, S.V. Bajay, and H. Rothman, Editors. 2000, Taylor and Francis: London. p. 183 -199. 
[5] Goldemberg, J., et al., Ethanol learning curve--the Brazilian experience. Biomass and Bioenergy, 2004. 26(3): p. 301-304.

[6] NCGA, World of Corn Consumption 2002. 2003, National Corn Growers Association http://www.ncga.com/03world/main/consumption.hm

[7] Eriksson, H.M.H, Hall J.P., Helynen, Satu, Rationale for forest energy production, in Forestry Sciences, J.B. Richardson, Björheden R.; Hakkila, P.; Lowe, A.T. and Smith, C.T., Editors. 2002, KluverAcademic Publishers: Dordrecht, NL. p. 1 - 17.

[8] Sokhansanj, S., Turhollow, A., Cushman, J., and Cundiff, J. Engineering aspects of collecting corn stover for bioenergy. Biomass and Bioenergy, 2002. 23(5): p. 347-355.

[9] Chum, H.L. and R.P. Overend, Biomass and Bioenergy in the United States, in Advances in Solar Energy: an Annual Review, Y. Goswami, Editor. 2003, American Solar Energy Society: Boulder, CO. USA. p. 83-148.

[10] Haq, Z., Biomass for Electricity Generation. 2002, Energy Information Administration http://www.eia.doe.gov/analysis/2001anal08.html

[11] Brown, R. C. (2003) Biorenewable Resources: Engineering New Products from Agriculture, Iowa State Press, Ames, IA.

[12] Borman, G. L. and Ragland, K. W. (1998) Combustion Engineering, McGraw-Hill.

[13] Jenkins, B. M., Baxter, L. L., Miles, Jr., T. R., and Miles, T. R. (1998) “Combustion properties of biomass, Fuel Process. Tech. 54, 17 - 46.

[14] Bridgwater, A. V. (1995) "The technical and economic feasibility of biomass gasification for power generation," Fuel 74, 631-653.

[15] Reed, T., editor (1981) Biomass Gasification: Principles and Technology, Noyes Data Corp., Park Ridge, N.J.

[16] Bridgwater, A., Czernik, S., Diebold, J., Meier, D., Oasmaa, A., Peacocke, C., Piskorz, J., and Radlein, D. (1999) Fast Pyrolysis of Biomass: A Handbook, CPL Press, Newbury, United Kingdom.

[17] Hickman, H. Lanier, “A Brief History of Solid Waste Management During the Last 50 Years", MSW Management, September/October 2001

[18] United States Department of Energy (DOE) Energy Efficiency and Renewable Energy (EERE) website at: http://www.eere.energy.gov/RE/bioenergy.html

[19] H.R. 6, the Energy Policy Act of 2003 which can be found at: http://thomas.loc.gov/cgi-bin/query/z?c108:H.R.6:

[20] From a letter Written to Maria Zannes at IWSA by Marianne Lamont Horinko with the Office of Solid Waste and Emergency Response and Jeffrey R. Holmstead of the Office of Air and Radiation on Feb. 14th, 2003.

[21] Hickman, H. Lanier, "A Brief History of Solid Waste Management During the Last 50 Years", MSW Management magazine, September/October 2001

[22] Rao, Chaudhuri, Garcia, Stormwind and Ruffle, "Multiple Pathway Health Risk Assessment of a Municipal Waste Resource Recovery Facility in Maryland", EM, August 2003

[23] U.S. E.P.A. "Municipal Solid Waste in The United States: 2001 Facts and Figures Executive Summary"

[24] ASSURE, "Energy from Waste Fact Sheets", www.assure.org

[25] U.S. E.P.A. "Municipal Solid Waste in The United States: 2001 Facts and Figures Executive Summary" 
[26] Statistic from the WTE Research and Technology Council website at: http://www.seas.columbia.edu/earth/wtert/wtertfaq.html

[27] World Energy Assessment, Energy and the Challenge of Sustainability, UNDP, 2000

[28] WEC-FAO (World Energy Council and Food and Agriculture Organization of the United Nations). 1999, The Challenge of Rural Energy Poverty in Developing Countries. London.

[29] World Bank, 1996, Rural Energy and Development: Improving Energy Supplies for Two Billion People. Washington, D.C. 1997. World Development Indicators, 1997. Washington, D.C.

[30] WRI (World Resources Institute), 1998. A Guide to the Global Environment. Oxford: Oxford University Press.

[31] Biocoal from Groundnut Shells - An Industrial Approach to Household Energy in Senegal, by Dipl.-Ing. Benjamin Jargstorf, FACTOR 4 ENEREGY PROJECTS, Wismar, Germany

[32] Coura Badiane, Senegal's Trade in Groundnuts: Economic, Social and Environmental Implications, TED Case Studies Number 646, December 2001

[33] Renewable Energy Technology Annex. Small Modular Biopower (SMB) for a Community Productive Use. Platform (C-PUP), ANNEX 2004, Ashden Trust Awards for Sustainable Energy Bioenergy Conversion for Sustainable Rural Enterprise in the Philippines A-1 


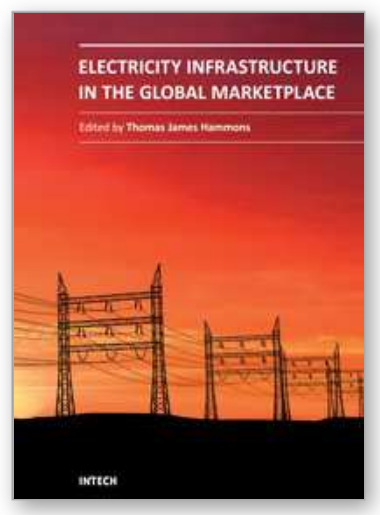

\author{
Electricity Infrastructures in the Global Marketplace \\ Edited by
}

ISBN 978-953-307-155-8

Hard cover, 802 pages

Publisher InTech

Published online 27, June, 2011

Published in print edition June, 2011

This book discusses trends in the energy industries of emerging economies in all continents. It provides the forum for dissemination and exchange of scientific and engineering information on the theoretical generic and applied areas of scientific and engineering knowledge relating to electrical power infrastructure in the global marketplace. It is a timely reference to modern deregulated energy infrastructure: challenges of restructuring electricity markets in emerging economies. The topics deal with nuclear and hydropower worldwide; biomass; energy potential of the oceans; geothermal energy; reliability; wind power; integrating renewable and dispersed electricity into the grid; electricity markets in Africa, Asia, China, Europe, India, Russia, and in South America. In addition the merits of GHG programs and markets on the electrical power industry, market mechanisms and supply adequacy in hydro-dominated countries in Latin America, energy issues under deregulated environments (including insurance issues) and the African Union and new partnerships for Africa's development is considered.

Thomas James Hammons (Fellow IEEE 1996) received the B.Sc. degree in Engineering (1st Class Honors), and the DIC, and Ph.D. degrees from Imperial College, London, UK He is a member of the teaching faculty of the School of Engineering, University of Glasgow, Scotland, UK. He was Professor of Electrical and Computer Engineering at McMaster University, Hamilton, Ontario, Canada in 1978-1979. He is the author/co-author of over 440 scientific articles and papers on electrical power engineering and is Editor of a book on Renewable Energy that was published by INTECH in December 2009. He has lectured extensively in North America, Africa, Asia, and both in Eastern and Western Europe.

Dr Hammons is Past Chair of the United Kingdom and Republic of Ireland (UKRI) Section IEEE and Past Chair of International Practices for Energy Development and Power Generation of IEEE. He is also a Past Chair of the IEEE PES Task Force on harmonizing power-engineering standards worldwide and Past Permanent Secretary of the International Universities Power Engineering Conference. He is a Chartered Engineer (CEng) and a registered European Engineer in the Federation of National Engineering Associations in Europe.

\title{
How to reference
}

In order to correctly reference this scholarly work, feel free to copy and paste the following:

T. J. Hammons (2011). Harnessing Untapped Biomass Potential Worldwide, Electricity Infrastructures in the Global Marketplace, (Ed.), ISBN: 978-953-307-155-8, InTech, Available from:

http://www.intechopen.com/books/electricity-infrastructures-in-the-global-marketplace/harnessing-untappedbiomass-potential-worldwide 
open science | open minds

InTech Europe

University Campus STeP Ri

Slavka Krautzeka 83/A

51000 Rijeka, Croatia

Phone: +385 (51) 770447

Fax: +385 (51) 686166

www.intechopen.com
InTech China

Unit 405, Office Block, Hotel Equatorial Shanghai

No.65, Yan An Road (West), Shanghai, 200040, China

中国上海市延安西路65号上海国际贵都大饭店办公楼 405 单元

Phone: +86-21-62489820

Fax: +86-21-62489821 
(C) 2011 The Author(s). Licensee IntechOpen. This chapter is distributed under the terms of the Creative Commons Attribution-NonCommercialShareAlike-3.0 License, which permits use, distribution and reproduction for non-commercial purposes, provided the original is properly cited and derivative works building on this content are distributed under the same license. 